\title{
FREQUENCY OF DIARRHOEA-ASSOCIATED VIRUSES IN SWINE OF VARIOUS AGES IN HUNGARY
}

\author{
Anna VAlKó ${ }^{1 *}$, András MAROSI $^{1}$, Attila CsÁGOLA $^{2}$, Rózsa FARKAs $^{3}$, Zsuzsanna RÓNAI $^{3}$ \\ and Ádám DÁN ${ }^{3}$ \\ ${ }^{1}$ Department of Microbiology and Infectious Diseases, University of Veterinary \\ Medicine Budapest, Hungária krt. 23-25, H-1143 Budapest, Hungary; \\ ${ }^{2}$ Ceva-Phylaxia Co. Ltd, Budapest, Hungary; ${ }^{3}$ National Food Chain Safety Office, \\ Veterinary Diagnostic Directorate, Budapest, Hungary
}

(Received 15 November 2018; accepted 15 February 2019)

Enteric viral diseases of swine are one of the most frequent disorders causing huge economic losses in pork production. After the reappearance of an emerging enteropathogen, porcine epidemic diarrhoea virus (PEDV) in Hungary in 2016, an extensive survey was initiated in an attempt to identify diarrhoea-related porcine viruses, including adeno-, astro-, boca-, calici-, circo-, corona-, kobu-, rota- and Torque teno viruses. A total of 384 faecal samples collected during a twoyear period from diarrhoeic and asymptomatic pigs of various ages in 17 farms were screened by conventional and real-time PCR methods. Half of the samples contained at least one examined virus with the dominance of kobuvirus $(55.1 \%)$ followed by bocaviruses (33.2\%) and rotavirus groups A and C together (20.9\%), while coronaviruses including PEDV were not found in this set of samples. Statistical analysis showed a highly significant difference $(\mathrm{P}<0.0001)$ in the frequency of single infections compared to mixed ones with the exception of weaned pigs, in which group additionally most viruses were detected. The results of this study suggest that the complexity of this disease may vary with age, which makes the prevention of diarrhoea a challenge, especially in weaned pigs.

Key words: Suckling and weaned pigs, enteropathogens, diarrhoea-associated viruses

Enteric diseases caused by viruses are highly prevalent and a source of huge economic losses in the swine industry (Zhang et al., 2013). Several viruses have been associated with diarrhoea, although there are still many viruses with an unclear aetiological role and only a part of them have been demonstrated to be enteropathogenic. Typical enteric viruses can be found among coronaviruses, which have attracted the greatest attention in this field recently, especially porcine epidemic diarrhoea virus (PEDV). Highly pathogenic variants of PEDV have appeared in Asia and North America, but in Europe mostly low pathogenic

*Corresponding author; E-mail: valko.anna@univet.hu; Phone: 0036 (1) 251-9900; Fax: 0036 (1) 251-9260 
PED viruses are present (Pensaert and Martelli, 2016). Transmissible gastroenteritis (TGE) is also caused by a coronavirus, and even though it became sporadic parallel with the appearance of porcine respiratory coronavirus (PRCV), its deletion mutant (Laude et al., 1993), TGE is still among the notifiable diseases listed by the World Organisation for Animal Health. Porcine deltacoronavirus (PDCoV), a relatively newly identified enteropathogenic coronavirus, was detected on the American and Asian continents (Mai et al., 2017) but has not been reported from Europe yet. In contrast, porcine rotavirus group A (PRVA) has a major role as a causative agent of diarrhoea worldwide, either alone or in mixed infections with other rotavirus groups (Lorenzetti et al., 2014), porcine rotavirus group B (PRVB) and group C (PRVC). Caliciviruses (CV) are emerging pathogens that cause the majority of non-bacterial gastroenteritis in humans, and the highly prevalent subclinical infection caused by them in pigs is an apparent concern regarding the possibility of zoonosis (Wang et al., 2006a). Porcine adenovirus (PAdV) has also been proved to be responsible for the development of diarrhoea through the destruction of epithelial cells (Ducatelle et al., 1982), although it is more common to find their characteristic inclusion bodies as collateral histopathological lesions (Sanford and Hoover, 1983). The pathogenicity of porcine circovirus type 2 (PCV2) has not been clarified yet, even though many diseases including enteritis are associated with it (Kim et al., 2004). However, immunosuppression caused by PCV2 may allow infection with other pathogens (Meng, 2013). Porcine astrovirus (PAdV) has been shown to have varying prevalence worldwide, although its clinical significance remains unclear, as it is often detected in healthy and diarrhoeic animals as well (Kumthip et al., 2018). Porcine bocavirus $(\mathrm{PBoV})$ has been identified in swine with enteric, respiratory, reproductive and general signs, although based on its high prevalence in healthy pigs it may act only as a predisposing factor in the development of different diseases (Zhou et al., 2014). Porcine kobuvirus (PKV) was first described in faecal samples of healthy pigs in Hungary (Reuter et al., 2008). Since then, PKV has also been detected frequently in samples of diarrhoeic animals, although often with other co-infecting viruses, further complicating the clarification of its role in enteric diseases (Jackova et al., 2017). Torque teno sus virus (TTSuV) may have a role as a triggering factor or an opportunistic pathogen in the emergence of other viral diseases, which was not evident regarding diarrhoea by its association with PRVA (de Arruda Leme et al., 2014).

All viruses mentioned above may contribute to the development of diarrhoea and might be present in the animal at the same time, since enteric disease of swine can be a complex disorder involving multiple microorganisms with a dominance of viruses (Katsuda et al., 2006). After the reappearance of PEDV in 2016 in Hungary (Valkó et al., 2017), an extensive survey was initiated to determine the frequency of PEDV and other diarrhoea-associated viruses. Our aim was to assess the occurrence of such viruses in faecal samples of healthy and di- 
arrhoeic pigs of various ages by PCR and conduct a comprehensive analysis about their presence on Hungarian pig farms for the first time in the country.

\section{Materials and methods}

A total of 384 faecal samples from 17 farrow-to-finish pig farms were collected from May 2016 to February 2018 throughout Hungary. Samples were collected from diarrhoeic and asymptomatic animals as controls from each farm, resulting in a total number of 239 diarrhoeic and 145 control samples. Pigs were divided into five age groups: one- (89), two- (76), three- to four-week-old (69) piglets, sows (78) and pigs within four weeks after weaning (72). Samples of sows were considered diarrhoeic, if they were collected from the mother of piglets with diarrhoea. All samples were collected from individual pigs, placed in security containers and kept under $+4{ }^{\circ} \mathrm{C}$ while transferred to the laboratory, where they were processed immediately or stored at $-80^{\circ} \mathrm{C}$.

About $0.5 \mathrm{~g}$ of faecal samples was homogenised in sterile phosphatebuffered saline (PBS) using a Tissue Lyser Instrument (Qiagen, Hilden, Germany). After centrifugation, the supernatant was used for nucleic acid extraction, which was carried out with MagAttract Virus Mini M48 Kit (Qiagen, Hilden, Germany) on a King Fisher 96 Flex instrument (Thermo Fisher Scientific Inc., Waltham, Massachusetts, USA) according to the manufacturer's instructions.

All samples were tested for coronaviruses with real-time PCR using Viroreal Kit PEDV\&SDCV and Viroreal Kit TGEV (Ingenetix GmbH, Wien, Austria), respectively. All other viruses were detected with conventional PCR on 96well PCR plates (Thermo Fisher Scientific Inc., Waltham, MA, USA) based on previously reported methods summarised in Table 1 . The reaction mixture for the PCR amplification of DNA viruses consisted of $5 \mu$ DreamTaq $5 \times$ Buffer (Thermo Fisher Scientific Inc., Waltham, MA, USA), $0.2 \mu 1$ DreamTaq DNA Polymerase (Thermo Fisher Scientific Inc., Waltham, MA, USA), $1 \mu 1$ of $1 \mathrm{mM}$ dNTP (Thermo Fisher Scientific Inc., Waltham, MA, USA), $1 \mu 1$ of $25 \mu \mathrm{M}$ forward and reverse primers, $2 \mu \mathrm{l}$ DNA template and $\mathrm{ddH}_{2} \mathrm{O}$ up to $50 \mu \mathrm{l}$. The reaction mixture for the PCR amplification of RNA viruses consisted of $10 \mu 1$ Xceed Taq 5× Buffer (Institute of Applied Biotechnologies, Strašnice, Czech Republic), $0.4 \mu 1$ Xceed Taq DNA Polymerase (Institute of Applied Biotechnologies, Strašnice, Czech Republic), $2 \mu 1$ of $25 \mu \mathrm{M}$ forward and reverse primers, and $2 \mu 1$ DNA template and $\mathrm{ddH}_{2} \mathrm{O}$ up to $50 \mu$ l. The PCR conditions used for different viruses are presented in Table 2. According to their sizes PCR products were run on $1.5 \%$ or $2 \%$ agarose gel stained with GR Safe Nucleic Acid Gel Stain (Excellgen, Rockville, MD, USA). A representative number of amplicons of the expected sizes were subjected to sequencing for verification. 
Table 1

Selected viruses for studying diarrhoeic and normal faecal samples of swine by conventional PCR listed with primer sets and product sizes in base pairs (bp) according to references

\begin{tabular}{|c|c|c|c|c|}
\hline Virus & & Primers & $\begin{array}{l}\text { Product size } \\
\quad \text { (bp) }\end{array}$ & Reference \\
\hline \multicolumn{5}{|l|}{ DNA viruses } \\
\hline PAdV & $\begin{array}{l}\mathrm{F} \\
\mathrm{R}\end{array}$ & $\begin{array}{l}\text { GCCGCARTGGTCYTACATGCACAT } \\
\text { CAGCRYRCCGCGGATGTCAAART }\end{array}$ & 256 & $\begin{array}{l}\text { Kiss et al., } \\
1996\end{array}$ \\
\hline PBoV1-2 & $\begin{array}{l}\mathrm{F} \\
\mathrm{R}\end{array}$ & $\begin{array}{l}\text { TGGTGGAACGTCTCTCTGACA } \\
\text { GAGTCATTCGGTCTCCTCCAT }\end{array}$ & 466 & $\begin{array}{l}\text { Cságola et al., } \\
2012\end{array}$ \\
\hline PBoV3-4 & $\begin{array}{l}\mathrm{F} \\
\mathrm{R}\end{array}$ & $\begin{array}{l}\text { GCACGGAGCTATTACTGGTT } \\
\text { AGCTGTAGACCGGATTGTGA }\end{array}$ & 310 & $\begin{array}{l}\text { Ndze et al., } \\
\quad 2013\end{array}$ \\
\hline PCV2 & $\begin{array}{l}\mathrm{F} \\
\mathrm{R}\end{array}$ & $\begin{array}{l}\text { GGAGGAGTAGTTTACATAGGGG } \\
\text { CGCACCTTCGGATATAC }\end{array}$ & 287 & $\begin{array}{l}\text { Cságola et al., } \\
2006\end{array}$ \\
\hline TTSuV1 & $\begin{array}{l}\mathrm{F} \\
\mathrm{R}\end{array}$ & $\begin{array}{l}\text { CGGGTTCAGGAGGCTCAAT } \\
\text { GCCATTCGGAACTGCACTTACT }\end{array}$ & 305 & \multirow{2}{*}{$\begin{array}{l}\text { Segalés et al., } \\
2009\end{array}$} \\
\hline TTSuV2 & $\begin{array}{l}\mathrm{F} \\
\mathrm{R}\end{array}$ & $\begin{array}{l}\text { TCATGACAGGGTTCACCGGA } \\
\text { CGTCTGCGCACTTACTTATATACTCTA }\end{array}$ & 252 & \\
\hline \multicolumn{5}{|l|}{ RNA viruses } \\
\hline PAstV & $\begin{array}{l}\mathrm{F} \\
\mathrm{R}\end{array}$ & $\begin{array}{l}\text { TGACATTTTGTGGATTTACAGTT } \\
\text { CACCCAGGGCTGACCA }\end{array}$ & 799 & $\begin{array}{l}\text { Reuter et al., } \\
\quad 2011\end{array}$ \\
\hline $\mathrm{CV}$ & $\begin{array}{l}\mathrm{F} \\
\mathrm{R}\end{array}$ & $\begin{array}{l}\text { GATTACTCCAAGTGGGACTCCAC } \\
\text { ACDATYTCATCATCACCATA }\end{array}$ & $\begin{array}{l}317(\mathrm{NoV}) \\
329(\mathrm{SaV})\end{array}$ & $\begin{array}{l}\text { Wang et al., } \\
2006 b\end{array}$ \\
\hline PKV & $\begin{array}{l}\mathrm{F} \\
\mathrm{R}\end{array}$ & $\begin{array}{l}\text { TGGATTACAAGTGTTTTGATGC } \\
\text { ATGTTGTTAATGATGGTGTTGA }\end{array}$ & 217 & $\begin{array}{l}\text { Yang et al., } \\
\quad 2014\end{array}$ \\
\hline PRVA & $\begin{array}{l}\mathrm{F} \\
\mathrm{R}\end{array}$ & $\begin{array}{l}\text { AAAGATGCTAGGGACAAAATTG } \\
\text { TTCAGATTGTGGAGCTATTCCA }\end{array}$ & 309 & $\begin{array}{l}\text { Elschner et al., } \\
2002\end{array}$ \\
\hline PRVB & $\begin{array}{l}\mathrm{F} \\
\mathrm{R}\end{array}$ & $\begin{array}{l}\text { CTATTCAGTGTGTCGTGAGAGG } \\
\text { CGTGGCTTTGGAAAATTCTTG }\end{array}$ & 434 & Gouvea et al. \\
\hline PRVC & $\begin{array}{l}\mathrm{F} \\
\mathrm{R}\end{array}$ & $\begin{array}{l}\text { CTCGATGCTACTACAGAATCAG } \\
\text { AGCCACATAGTTCACATTTCATCC }\end{array}$ & 356 & 1991 \\
\hline
\end{tabular}

PAdV: porcine adenovirus, $\mathrm{PBoV}$ : porcine bocavirus, $\mathrm{PCV}$ : porcine circovirus, TTSuV: Torque teno sus virus, $\mathrm{PAstV}$ : porcine astrovirus, $\mathrm{CV}$ : calicivirus, NoV: norovirus, $\mathrm{SaV}$ : sapovirus, $\mathrm{PKV}$ : porcine kobuvirus, PRVA: porcine rotavirus A, PRVB: porcine rotavirus B, PRVC: porcine rotavirus $\mathrm{C}$

Statistical analysis was conducted with the software GraphPad Prism version 7.0 (GraphPad Software, La Jolla, CA, USA) by using chi-squared test, Fisher's exact test and binomial distribution. 
Table 2

PCR conditions used for the detection of different diarrhoea-associated viruses in 35 cycles

\begin{tabular}{lccccccc}
\hline & $\begin{array}{c}\text { DNA } \\
\text { viruses }\end{array}$ & PAstV & $\mathrm{CV}$ & PKV & PRVA & PRVB & PRVC \\
\hline \multirow{3}{*}{ Initial denaturation } & $94{ }^{\circ} \mathrm{C}$ & $94{ }^{\circ} \mathrm{C}$ & $94{ }^{\circ} \mathrm{C}$ & $94{ }^{\circ} \mathrm{C}$ & $94{ }^{\circ} \mathrm{C}$ & $94{ }^{\circ} \mathrm{C}$ & $94{ }^{\circ} \mathrm{C}$ \\
& $5 \mathrm{~min}$ & $5 \mathrm{~min}$ & $3 \mathrm{~min}$ & $5 \mathrm{~min}$ & $5 \mathrm{~min}$ & $5 \mathrm{~min}$ & $5 \mathrm{~min}$ \\
Denaturation & $94{ }^{\circ} \mathrm{C}$ & $94{ }^{\circ} \mathrm{C}$ & $94{ }^{\circ} \mathrm{C}$ & $94{ }^{\circ} \mathrm{C}$ & $94{ }^{\circ} \mathrm{C}$ & $94{ }^{\circ} \mathrm{C}$ & $94{ }^{\circ} \mathrm{C}$ \\
& $30 \mathrm{sec}$ & $30 \mathrm{sec}$ & $30 \mathrm{sec}$ & $30 \mathrm{sec}$ & $30 \mathrm{sec}$ & $30 \mathrm{sec}$ & $30 \mathrm{sec}$ \\
Annealing & $55{ }^{\circ} \mathrm{C}$ & $45^{\circ} \mathrm{C}$ & $48{ }^{\circ} \mathrm{C}$ & $52{ }^{\circ} \mathrm{C}$ & $52{ }^{\circ} \mathrm{C}$ & $57{ }^{\circ} \mathrm{C}$ & $54{ }^{\circ} \mathrm{C}$ \\
& $30 \mathrm{seC}$ & $45 \mathrm{sec}$ & $40 \mathrm{sec}$ & $40 \mathrm{sec}$ & $30 \mathrm{sec}$ & $30 \mathrm{sec}$ & $30 \mathrm{sec}$ \\
Extension & $72{ }^{\circ} \mathrm{C}$ & $72{ }^{\circ} \mathrm{C}$ & $72{ }^{\circ} \mathrm{C}$ & $72{ }^{\circ} \mathrm{C}$ & $72{ }^{\circ} \mathrm{C}$ & $72{ }^{\circ} \mathrm{C}$ & $72{ }^{\circ} \mathrm{C}$ \\
& $40 \mathrm{sec}$ & $45 \mathrm{sec}$ & $40 \mathrm{sec}$ & $40 \mathrm{sec}$ & $40 \mathrm{sec}$ & $40 \mathrm{sec}$ & $40 \mathrm{sec}$ \\
Final elongation & $72{ }^{\circ} \mathrm{C}$ & $72{ }^{\circ} \mathrm{C}$ & $72{ }^{\circ} \mathrm{C}$ & $72{ }^{\circ} \mathrm{C}$ & $72{ }^{\circ} \mathrm{C}$ & $72{ }^{\circ} \mathrm{C}$ & $72{ }^{\circ} \mathrm{C}$ \\
& $7 \mathrm{~min}$ & $10 \mathrm{~min}$ & $7 \mathrm{~min}$ & $7 \mathrm{~min}$ & $7 \mathrm{~min}$ & $7 \mathrm{~min}$ & $7 \mathrm{~min}$ \\
\hline
\end{tabular}

PAstV: porcine astrovirus, CV: calicivirus, PKV: porcine kobuvirus, PRVA: porcine rotavirus A, PRVC: porcine rotavirus $\mathrm{C}$

\section{Results}

Out of 239 diarrhoeic samples, $52.3 \%$ contained at least one examined virus and a slightly lower rate of $49.0 \%$ was detected from 145 control samples. All examined farms had positive samples, and viruses were detected from diarrhoeic and control samples as well with the exception of one farm, where they were found viruses only in diarrhoeic samples. Out of the total sample number of 384 samples, 196 contained at least one examined virus with a significantly higher $(\mathrm{P}<0.0001)$ number of single infections, although there was no virus which was found in single infections only. There were 126 single and 70 mixed infections involving two (44), three (19) or four (7) viruses at the same time. Mixed infections were slightly more frequent in control samples, as they were detected in $36.6 \%$ of the positive control samples and $35.2 \%$ of the positive diarrhoeic samples.

PKV was found most frequently in $55.1 \%$ of the positive samples at almost all 17 farms with one exception. The second most frequently detected viruses were PBoV1-2 and PBoV3-4 together at 14 farms with a frequency of $33.2 \%$, followed by PRVA and PRVC together at 11 farms with $20.9 \%$. The detection rate of all other examined viruses did not reach 15\%: PAdV - 10 farms, $14.3 \%$, PAstV -8 farms, $13.8 \%$, PCV2 - 5 farms, $7.7 \%$, CV -6 farms, $5.6 \%$, TTSuV1 - 2 farms, $1.0 \%$, TTSuV2 - 1 farm, 1.0\%. Coronaviruses (PEDV, PDCoV, TGEV) and PRVB were not found in the examined samples. TTSuV1 was found only in control and TTSuV2 only in diarrhoeic samples, while all oth- 
er viruses were detected in both health statuses, as illustrated by Fig. 1. Positive control samples were detected usually beside positive diarrheic samples of the same group, although all viruses with the exception of PCV2 were found in a few positive control samples alone as well. Statistical analysis of each virus showed that only rotaviruses were found in a significantly higher $(\mathrm{P}=0.0275)$ number in diarrhoeic samples compared to the controls.

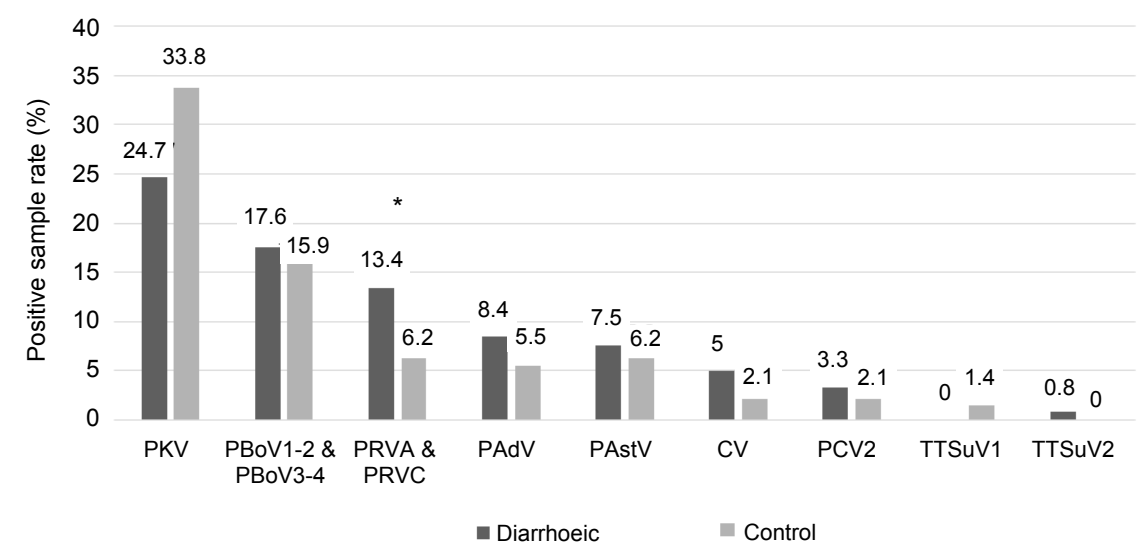

Fig. 1. Distribution of positive samples in percent of all diarrhoeic $(n=239)$ and control $(n=145)$ samples by viruses and health status. Significant difference $(P=0.0275)$ between diarrhoeic and

control samples is indicated with an asterisk $(*)$. PKV: porcine kobuvirus, $\mathrm{PBoV}$ : porcine bocavirus, PRVA: porcine rotavirus A, PRVC: porcine rotavirus $\mathrm{C}, \mathrm{PAdV}$ : porcine adenovirus, PAstV: porcine astrovirus, $\mathrm{CV}$ : calicivirus, $\mathrm{PCV}$ : porcine circovirus, TTSuV: Torque teno sus virus

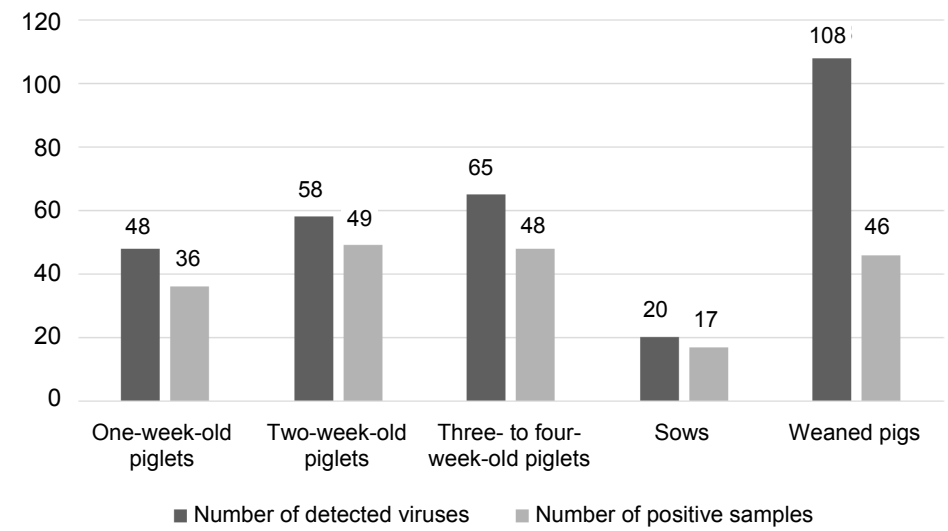

Fig. 2. Comparison of the number of detected viruses and positive samples in different age groups of pigs. Note the high number of detected viruses in weaned pigs from a relatively small amount of positive samples showing a higher rate of mixed infections in this age group 
The 125 positive diarrhoeic samples were distributed by age as follows: $17.6 \%$ one-week-old piglets, $24 \%$ two-week-old piglets, $23.2 \%$ three- to fourweek-old piglets, $7.2 \%$ sows and $28 \%$ weaned pigs. There was an overall significant difference $(\mathrm{P}<0.0001)$ in the number of detected viruses and the comparison of each age group showed non-significant difference only between twoweek-old and three- to four-week-old piglets. The highest number of viruses was found in weaned pigs (Fig. 2) and the rate of mixed infections correlated to the number of positive samples of each group was also the highest in weaned pigs with $76.1 \%$, while it reached only $30.6 \%$ in one-week-old piglets, $16.3 \%$ in twoweek-old piglets, $29.2 \%$ in three- to four-week-old piglets and $11.8 \%$ in sows. The exact number of different viruses detected in pigs of various ages is summarised in Table 3.

Table 3

Distribution of detected viruses by age with the indication of health status in parenthesis (diarrhoeic : control)

\begin{tabular}{lcccccc}
\hline Virus & $\begin{array}{c}\text { One-week- } \\
\text { old piglets }\end{array}$ & $\begin{array}{c}\text { Two-week- } \\
\text { old piglets }\end{array}$ & $\begin{array}{c}\text { Three- to } \\
\text { four-week- } \\
\text { old piglets }\end{array}$ & Sows & $\begin{array}{c}\text { Weaned } \\
\text { pigs }\end{array}$ & Total \\
\hline PAdV & $2(1: 1)$ & $4(3: 1)$ & $7(7: 0)$ & $2(0: 2)$ & $13(9: 4)$ & $28(20: 8)$ \\
PAstV & $1(0: 1)$ & $1(0: 1)$ & $6(3: 3)$ & $1(0: 1)$ & $18(15: 3)$ & $27(18: 9)$ \\
PBoV1-2 & 0 & $2(2: 0)$ & 0 & $4(2: 2)$ & $19(15: 4)$ & $25(19: 6)$ \\
PBoV3-4 & $1(0: 1)$ & $1(0: 1)$ & $4(1: 3)$ & $12(6: 6)$ & $22(16: 6)$ & $40(23: 17)$ \\
CV & 0 & $1(1: 0)$ & $3(3: 0)$ & 0 & $11(8: 3)$ & $15(12: 3)$ \\
PKV & $28(15: 13)$ & $36(19: 17)$ & $35(20: 15)$ & 0 & $9(5: 4)$ & $108(59: 49)$ \\
PCV2 & 0 & $1(1: 0)$ & $3(2: 1)$ & $1(1: 0)$ & $6(4: 2)$ & $11(8: 3)$ \\
PRVA & $9(7: 2)$ & $11(6: 5)$ & $6(6: 0)$ & 0 & $8(8: 0)$ & $34(27: 7)$ \\
PRVC & $7(5: 2)$ & 0 & 0 & 0 & 0 & $7(5: 2)$ \\
TTSuV1 & 0 & $1(0: 1)$ & $1(0: 1)$ & 0 & 0 & $2(0: 2)$ \\
TTSuV2 & 0 & 0 & 0 & 0 & $2(2: 0)$ & $2(2: 0)$ \\
Total & $48(28: 20)$ & $58(32: 26)$ & $65(42: 23)$ & $20(9: 11)$ & $108(82: 26)$ & $299(193: 106)$ \\
\hline
\end{tabular}

PAdV: porcine adenovirus, PAstV: porcine astrovirus, $\mathrm{PBoV}$ : porcine bocavirus, $\mathrm{CV}$ : calicivirus, PKV: porcine kobuvirus, PCV: porcine circovirus, PRVA: porcine rotavirus A, PRVC: porcine rotavirus $\mathrm{C}$, TTSuV: Torque teno sus virus

\section{Discussion}

A total of 384 faecal samples from 17 farms were collected in Hungary in a two-year period in an attempt to assess the prevalence of viruses associated with diarrhoea in swine. In contrast to previous studies (Katsuda et al., 2006; Zhang et al., 2013), the dominance of viruses was not outstanding in this survey, as $52.3 \%$ of diarrhoeic samples contained at least one examined virus, and a slightly lower positivity rate $(49.0 \%)$ was detected in the control samples. How- 
ever, positive control samples were identified usually from the same group of animals with positive diarrhoeic samples, which suggests that the viral infection may have persisted after the clinical signs ceased. The relatively high amount of negative diarrhoeic samples may be explained by the presence of other factors (other microorganisms, food and hygiene management) that might be more favourable for the farms based on the more accessible treatment and prevention (antibiotics, improved hygiene protocols) against these.

Surprisingly, PEDV was not found in any samples, as opposed to what has been assumed after the reappearance of the virus in the country in 2016 (Valkó et al., 2017). The case was similar with TGEV, which was detected for the last time in Hungary in 2013 (Lörincz et al., 2014), although the absence of this coronavirus may be explained by the cross-protection provided by antibodies produced against PRCV. The absence of these coronaviruses is similar to that found in a Slovakian study, where neither PEDV nor TGEV was detected from 411 rectal swabs collected between the years 2013 and 2016 (Salamunova et al., 2018). PDCoV has not been reported from Europe yet, and was not detected in this survey either, although it has been discovered in the USA, Canada and many Asian countries (Mai et al., 2017). PKV was detected most commonly with a frequency of $55.1 \%$. A previous study found a significant difference in the proportion of diarrhoeic $(92.3 \%$ of 26$)$ samples in comparison with healthy $(54.5 \%$ of 11$)$ ones (Zhou et al., 2016), which contradicts our results, although the number of tested samples was quite different. We detected PKV in 59 diarrhoeic and 49 control samples, but the calculation of the ratio of positive samples in relation to the total number of diarrhoeic (239) and control (145) samples showed an even higher percentage among the controls (Fig. 1). A high prevalence of PKV in healthy pigs is not uncommon; a similar study in the Czech Republic found $87.3 \%$ PKV positivity in 145 faecal and 51 intestinal content samples collected from healthy animals (Dufkova et al., 2013). Still, it cannot be excluded that PKV may have contributed to the development of an enteric disease in suckling piglets, since most PKV cases were detected in this age group in our study (Table 3), and the role of PKV as a causative agent has been confirmed in piglets previously (Yang et al., 2015). The second most frequently detected viruses were different PBoVs, which were more prevalent in weaned pigs with respiratory signs (Zhai et al., 2010 ) and also with diarrhoea in this case. Compared to a large-scale study (Marthaler et al., 2014), where $83 \%$ of 7,508 diarrhoeic samples were positive for porcine rotaviruses, they were infrequent in this case with a detection rate of $13.4 \%$ from 239 diarrhoeic samples, but still significantly higher compared to $6.2 \%$ out of 145 control samples. These results are similar to other findings from Central Europe, as $17.2 \%$ of 163 samples from diarrhoeic and $6.8 \%$ of 251 samples from healthy pigs tested positive for PRVA in a Slovakian study (Jackova et al., 2017). The detection rate of all other examined viruses was quite low, hindering the calculation of statistical significance. Still, with the exception of PKV 
and TTSuV1 they were found more frequently in diarrhoeic samples, suggesting their contribution to the development of the disease. Further research involving the same set of samples with different, for example metagenomic methods may confirm the relatively low frequency of examined viruses in Hungary and provide new aspects about their role in diarrhoea. The different approach in methods (conventional, nested or real-time PCR and metagenomics), as well as the type of investigated samples (faeces, intestinal content and rectal swabs) should also explain the differences in the results of our study compared to other prevalence studies, providing further inspiration in planning new research in order to reach a more accurate comparison, especially with neighbouring countries.

In relation to age, the highest number of examined viruses were detected in weaned pigs and the complexity of the infection also differed in this age group (Fig. 2). In contrast, single infections were more frequent in all suckling piglet groups, resulting in the overall significant dominance of single infections. The lowest number of detected viruses and positive samples were found in sows, which indicates that even if their piglets were infected, the infection of sows did not reach a detectable level of virus shedding in most cases. These findings show that our hypothesis regarding the higher prevalence of co-infection with different viruses at the same time based on previous reports (Shan et al., 2011; Zhang et al., 2013) may stand only for weaned pigs. Activation of the immune system of the gastrointestinal tract during weaning (Bauer et al., 2006) may prevent the development of an enteric disease caused by a single virus in weaned pigs, which emphasises the importance of a complex diagnostic approach in the examination of diarrhoea in this age group.

\section{Acknowledgement}

This project was funded by the NKB 2016 grant of the University of Veterinary Medicine Budapest.

\section{References}

Bauer, E., Williams, B. A., Smidt, H., Verstegen, M. W. and Mosenthin, R. (2006): Influence of the gastrointestinal microbiota on development of the immune system in young animals. Curr. Issues Intest. Microbiol. 7, 35-51.

Cságola, A., Kecskeméti, S., Kardos, G., Kiss, I. and Tuboly, T. (2006): Genetic characterization of type 2 porcine circoviruses detected in Hungarian wild boars. Arch. Virol. 151, 495-507.

Cságola, A., Lőrincz, M., Cadar, D., Tombácz, K., Biksi, I. and Tuboly, T. (2012): Detection, prevalence and analysis of emerging porcine parvovirus infections. Arch. Virol. 157, $1003-1010$.

de Arruda Leme, R., Lorenzetti, E., Alfieri, A. F. and Alfieri, A. A. (2014): Detection of Torque teno sus virus in diarrheic piglet fecal samples positive or negative for porcine group A rotavirus. J. Swine Health Prod. 22, 287-290.

Ducatelle, R., Coussement, W. and Hoorens, J. (1982): Sequential pathological study of experimental porcine adenovirus enteritis. Vet. Pathol. 19, 179-189. 
Dufkova, L., Scigalkova, I., Moutelikova, R., Malenovska, H. and Prodelalova, J. (2013): Genetic diversity of porcine sapoviruses, kobuviruses, and astroviruses in asymptomatic pigs: an emerging new sapovirus GIII genotype. Arch. Virol. 158, 549-558.

Elschner, M., Prudlo, J., Hotzel, H., Otto, P. and Sachse, K. (2002): Nested reverse transcriptasepolymerase chain reaction for the detection of Group A rotaviruses. J. Vet. Med. B 49, 77-81.

Gouvea, V., Allen, J. R., Glass, R. I., Fang, Z.-Y., Bremont, M., Cohen, J., McCrae, M. A., Saif, S. L. J., Sinarachatanant, P. and Caul, E. O. (1991): Detection of group B and C rotaviruses by polymerase chain reaction. J. Clin. Microbiol. 29, 519-523.

Jackova, A., Sliz, I., Mandelik, R., Salamunova, S., Novotny, J., Kolesarova, M., Vlasakova, M. and Vilcek, S. (2017): Porcine kobuvirus 1 in healthy and diarrheic pigs: Genetic detection and characterization of virus and co-infection with rotavirus A. Infect. Genet. Evol. 49, 73-77.

Katsuda, K., Kohmoto, M., Kawashima, K. and Tsunemitsu, H. (2006): Frequency of enteropathogen detection in suckling and weaned pigs with diarrhea in Japan. J. Vet. Diagn. Invest. 18, $350-354$

Kim, J., Ha, Y., Jung, K., Choi, C. and Chae, C. (2004): Enteritis associated with porcine circovirus 2 in pigs. Can. J. Vet. Res. 68, 218-221.

Kiss, I., Matiz, K., Allard, A., Wadell, G. and Benkő, M. (1996): Detection of homologous DNA sequences in animal adenoviruses by polymerase chain reaction. Acta Vet. Hung. 44, 243-251.

Kumthip, K., Khamrin, P., Saikruang, W., Kongkaew, A., Vachirachewin, R., Ushijima, H. and Maneekarn, N. (2018): Detection and genetic characterization of porcine astroviruses in piglets with and without diarrhea in Thailand. Arch. Virol. 163, 1823-1829.

Laude, H., Van Reeth, K. and Pensaert, M. (1993): Porcine respiratory coronavirus: molecular features and virus-host interactions. Vet. Res. 24, 125-150.

Lorenzetti, E., Stipp, D. T., Possatti, F., Campanha, J. E. T., Alfieri, A. F. and Alfieri, A. A. (2014): Diarrhea outbreaks in suckling piglets due to rotavirus group $\mathrm{C}$ single and mixed (rotavirus groups A and B) infections. Pesqui. Vet. Brasil. 34, 391-397.

Lőrincz, M., Biksi, I., Andersson, S., Cságola, A. and Tuboly, T. (2014): Sporadic re-emergence of enzootic porcine transmissible gastroenteritis in Hungary. Acta Vet. Hung. 62, 125-133.

Mai, K., Feng, J., Chen, G., Li, D., Zhou, L., Bai, Y., Wu, Q. and Ma, J. (2017): The detection and phylogenetic analysis of porcine deltacoronavirus from Guangdong Province in Southern China. Transbound. Emerg. Dis. 65, 166-173.

Marthaler, D., Homwong, N., Rossow, K., Culhane, M., Goyal, S., Collins, J., Matthijnssens, J. and Ciarlet, M. (2014): Rapid detection and high occurrence of porcine rotavirus A, B, and C by RT-qPCR in diagnostic samples. J. Virol. Methods 209, 30-34.

Meng, X.-J. (2013): Porcine circovirus type 2 (PCV2): Pathogenesis and interaction with the immune system. Annu. Rev. Anim. Biosci. 1, 43-64.

Ndze, V. N., Cadar, D., Cságola, A., Kisfali, P., Kovács, E., Farkas, S., Ngu, A. F., Esona, M. D., Dán, Á., Tuboly, T. and Bányai, K. (2013): Detection of novel porcine bocaviruses in fecal samples of asymptomatic pigs in Cameroon. Infect. Genet. Evol. 17, 277-282.

Pensaert, M. B. and Martelli, P. (2016): Porcine epidemic diarrhea: A retrospect from Europe and matters of debate. Virus Res. 226, 1-6.

Reuter, G., Boldizsár, Á., Kiss, I. and Pankovics, P. (2008): Candidate new species of kobuvirus in porcine hosts. Emerg. Infect. Dis. 14, 1968-1970.

Reuter, G., Pankovics, P. and Boros, Á. (2011): Identification of a novel astrovirus in a domestic pig in Hungary. Arch. Virol. 156, 125-128.

Salamunova, S., Jackova, A., Mandelik, R., Novotny, J., Vlasakova, M. and Vilcek, S. (2018): Molecular detection of enteric viruses and the genetic characterization of porcine astroviruses and sapoviruses in domestic pigs from Slovakian farms. BMC Vet. Res. 14, 313-321.

Sanford, S. E. and Hoover, D. M. (1983): Enteric adenovirus infection in pigs. Can. J. Comp. Med. 47, 396-400. 
Segalés, J., Martínez-Guíno, L., Cortey, M., Navarro, N., Huerta, E., Sibila, M., Pujols, J. and Kekarainen, T. (2009): Retrospective study on swine Torque teno virus genogroups 1 and 2 infection from 1985 to 2005 in Spain. Vet. Microbiol. 134, 199-207.

Shan, T., Li, L., Simmonds, P., Wang, C., Moeser, A. and Delwart, E. (2011): The fecal virome of pigs on a high-density farm. J. Virol. 85, 11697-11708.

Valkó, A., Biksi, I., Cságola, A., Tuboly, T., Kiss, K., Ursu, K. and Dán, Á. (2017): Porcine epidemic diarrhoea virus with a recombinant S gene detected in Hungary, 2016. Acta Vet. Hung. 65, 253-261.

Wang, Q.-H., Chang, K.-O., Han, M. G., Sreevatsan, S. and Saif, L. J. (2006b): Development of a new microwell hybridization assay and an internal control RNA for the detection of porcine noroviruses and sapoviruses by reverse transcription-PCR. J. Virol. Methods 132, 135-145.

Wang, Q.-H., Souza, M., Funk, J. A., Zhang, W. and Saif, L. J. (2006a): Prevalence of noroviruses and sapoviruses in swine of various ages determined by reverse transcription-PCR and microwell hybridization assays. J. Clin. Microbiol. 44, 2057-2062.

Yang, F., Liu, X., Zhou, Y., Lyu, W., Xu, S., Xu, Z. and Zhu, L. (2015): Histopathology of Porcine kobuvirus in Chinese piglets. Virol. Sin. 30, 396-399.

Yang, Z., Jin, W., Zhao, Z., Lin, W., Zhang, D., Yu, E., Qin, A. and Yang, H. (2014): Genetic characterization of porcine kobuvirus and detection of coinfecting pathogens in diarrheic pigs in Jiangsu Province, China. Arch. Virol. 159, 3407-3412.

Zhai, S., Yue, C., Wei, Z., Long, J., Ran, D., Lin, T., Deng, Y., Huang, L., Sun, L., Zheng, H. et al. (2010): High prevalence of a novel porcine bocavirus in weanling piglets with respiratory tract symptoms in China. Arch. Virol. 155, 1313-1317.

Zhang, Q., Hu, R., Tang, X., Wu, C., He, Q., Zhao, Z., Chen, H. and Wu, B. (2013): Occurrence and investigation of enteric viral infections in pigs with diarrhea in China. Arch. Virol. 158, 1631-1636.

Zhou, F., Sun, H. and Wang, Y. (2014): Porcine bocavirus: Achievements in the past five years. Viruses 6, 4946-4960.

Zhou, W., Ullman, K., Chowdry, V., Reining, M., Benyeda, Z., Baule, C., Juremalm, M., Wallgren, P., Schwarz, L., Zhou, E., Pedrero, S. P., Hennig-Pauka, I., Segalés, J. and Liu, L. (2016): Molecular investigations on the prevalence and viral load of enteric viruses in pigs from five European countries. Vet. Microbiol. 182, 75-81.

This is an open-access article distributed under the terms of the Creative Commons Attribution 4.0 International License (https://creativecommons.org/licenses/by/4.0/), which permits unrestricted use, distribution, and reproduction in any medium, provided the original author and source are credited, a link to the CC License is provided, and changes - if any - are indicated. (SID_1) 